\section{Response of Selected Nursery Crop Plants to Inoculation with Isolates of Phytophthora ramorum and Other Phytophthora Species}

\author{
R.G. Linderman ${ }^{1}$, E.A. Davis, and J.L. Marlow
}

AdDitional INDEX wORDs. ornamentals, Phytophthora cactorum, P. cinnamomi, $P$. citricola, $P$. citrophthora, $P$. beveae, $P$. nicotianae (= parasitica), $P$. syringae, sudden oak death, ramorum blight

Summary. Many nursery crops are susceptible to root and foliage diseases caused by numerous species of Phytophthora. Phytophthora ramorum causes sudden oak death of trees and ramorum leaf blight and shoot dieback on numerous nursery plants, including rhododendron (Rhododendron spp.), viburnum (Viburnum spp.), pieris (Pieris spp.), and camellia (Camellia spp.) in Europe, the United States, and British Columbia, Canada. We sought to evaluate relative susceptibility of a selection of ornamental nursery crops by inoculating detached leaves with several species of Phytophthora known to infect rhododendrons, and to compare the relative virulence on those species to isolates of $P$. vamorum. The results indicated that many plants were susceptible under these experimental conditions, while others were not. On a given host, symptoms caused by all species of Phytophthora were identical except for differences in pathogen virulence. Plant species within genera or cultivars within species varied in susceptibility to isolates of $P$. ramorum and other species of Phytophthora. Phytophthora ramorum, P. citricola, $P$. citrophthora, and $P$. nicotianae were the most virulent pathogens on most of the host plants inoculated. Some plants were susceptible to several species of Phytophthora, while others were susceptible only to P. ramorum. Inoculation of detached leaves of 'Nova Zembla' rhododendron, lilac (Syringa vulgaris), or doublefile viburnum (Viburnum plicatum var. tomentosum) under controlled conditions with different species of Phytophthora or isolates of P. ramorum (both mating types) indicated significant relative differences in species or isolate virulence.

$\mathrm{T}$ he discovery of the sudden oak death pathogen, Phytophthora ramorum, killing trees and shrubs in the forests of California and Oregon as well as causing leaf blight and shoot dieback on ornamental plants, in nurseries and landscapes in several European countries and the United States, underscores the threat that this pathogen poses to the nurseries that grow susceptible plants, especially those in the Ericaceae [such as rhododendron, mountain-laurel (Kalmiaspp.), pieris, and huckleberry (Vaccinium spp.)], Fagaceae [oak (Quercus spp.), tanoak, (Lithocarpus spp.), and beech (Fagus spp.)], and Caprifoliaceae (Viburnum

USDA-Agricultural Research Service, Horticultural Crops Research Laboratory, 3420 NW Orchard Avenue, Corvallis, OR 97330

We acknowledge the excellent assistance in this work of Bryan Beck, Jesse Mitchell, and AmberWierck. Mention of a trademark, proprietary product, or vendor does not constitute a guarantee or warranty of the product by the U.S. Department of Agriculture and does not imply its approval to the exclusion of other products or vendors that also may be suitable.

${ }^{1}$ Research Plant Pathologist; to whom reprint requests should be addressed. Telephone: 541-738-4062; fax: 54-738-4025; e-mail: lindermr@science.oregonstate. edu spp.) (Davidson et al., 2003; Goheen et al., 2002; Parke et al., 2004; Rizzo et al., 2002; Werres et al., 2001). The leaf blight symptoms caused by P. ramorum on rhododendrons (Werres et al., 2001) are remarkably similar to those caused by other species of Phytophthora known to exist in the nursery industry, especially P. syringae (Linderman, 1986) and others (Coyier and Roane, 1986; Daughtrey and Benson, 2001). This dilemma makes visual diagnosis of $P$. ramorum infections in nurseries difficult. Furthermore, it is necessary that inspectors, looking for signs of infection by this quarantined pathogen, have an expanded knowledge of the potential symptoms and host range. In addition, the relative virulence of $P$. ramorum compared to other species of Phytophthora on nursery crops is not known.
Therefore, the objectives of this research were to answer the following questions: 1) How susceptible are some commonly grown nursery plants to infection by $P$. ramorum, and are some resistant? 2) Are there any distinguishing symptoms of $P$. ramorum infections compared to infections by other Phytophthora species? 3) How virulent is $P$. ramorum compared to other species known to infect rhododendrons or other nursery plants, including $P$. cactorum, P. cambivora, P. cinnamomi, P. citricola, P. citrophthora, $P$. heveae, $P$. nicotianae ( $=P$. parasitica), and $P$. syringae (Osterbauer et al., 2004)? Preliminary findings of isolate variability have been reported (Linderman et al., 2002).

\section{Materials and methods}

Cultures, inOculation, AND DISEASE SEVERITY RATINGS. Isolates of Phytophthora spp. were obtained from cultures originally isolated from plants in Oregon within recent years (Table 1). Cultures were maintained and stored under refrigeration on agar slants until used, and then were transferred frequently on dilute V8 juice agar plates $\left[30 \mathrm{~mL} \cdot \mathrm{L}^{-1}\right.$ of clarified V8 juice instead of the normal 150-200 $\mathrm{mL} \cdot \mathrm{L}^{-1}$ (Ribeiro, 1978)].

Inoculum was prepared by growing isolates on dilute V8 juice agar medium for $14 \mathrm{~d}$ in an incubator at 20 ${ }^{\circ} \mathrm{C}$. We inoculated with mycelium plugs taken from the margins of colonies to be consistent among the Phytophthora species, most of which do not sporulate as profusely on solid media as $P$. ramorum (Rizzo et al., 2002; Tooley et al., 2004), even though sporangia or zoospores are more natural forms of inoculum.

In all studies, inoculated leaves first were wounded with a single needle probe. They were inoculated with mycelium plugs (6-mm diameter) by inverting a plug onto a wound site on the upper side of the leaves. For small-leaf species [such as spreading cotoneaster (Cotoneaster divaricatus)], one plug was placed on three adjacent leaves on a detached shoot, and the control plug (no pathogen) was placed on a

\begin{tabular}{llll}
\hline $\begin{array}{l}\text { Units } \\
\begin{array}{l}\text { To convert U.S. to SI, } \\
\text { multiply by }\end{array}\end{array}$ & U.S. unit & SI unit & $\begin{array}{l}\text { To convert SI to U.S., } \\
\text { multiply by }\end{array}$ \\
\hline 0.4047 & acre $(\mathrm{s})$ & $\mathrm{ha}$ & 2.4711 \\
25.4 & inch(es) & $\mathrm{mm}$ & 0.0394 \\
$\left({ }^{\circ} \mathrm{F}-32\right) \div 1.8$ & ${ }^{\circ} \mathrm{F}$ & ${ }^{\circ} \mathrm{C}$ & $\left(1.8 \times{ }^{\circ} \mathrm{C}\right)+32$
\end{tabular}


Table 1. Source of isolates (all from Oregon) of species of Phytophthora used in inoculation experiments.

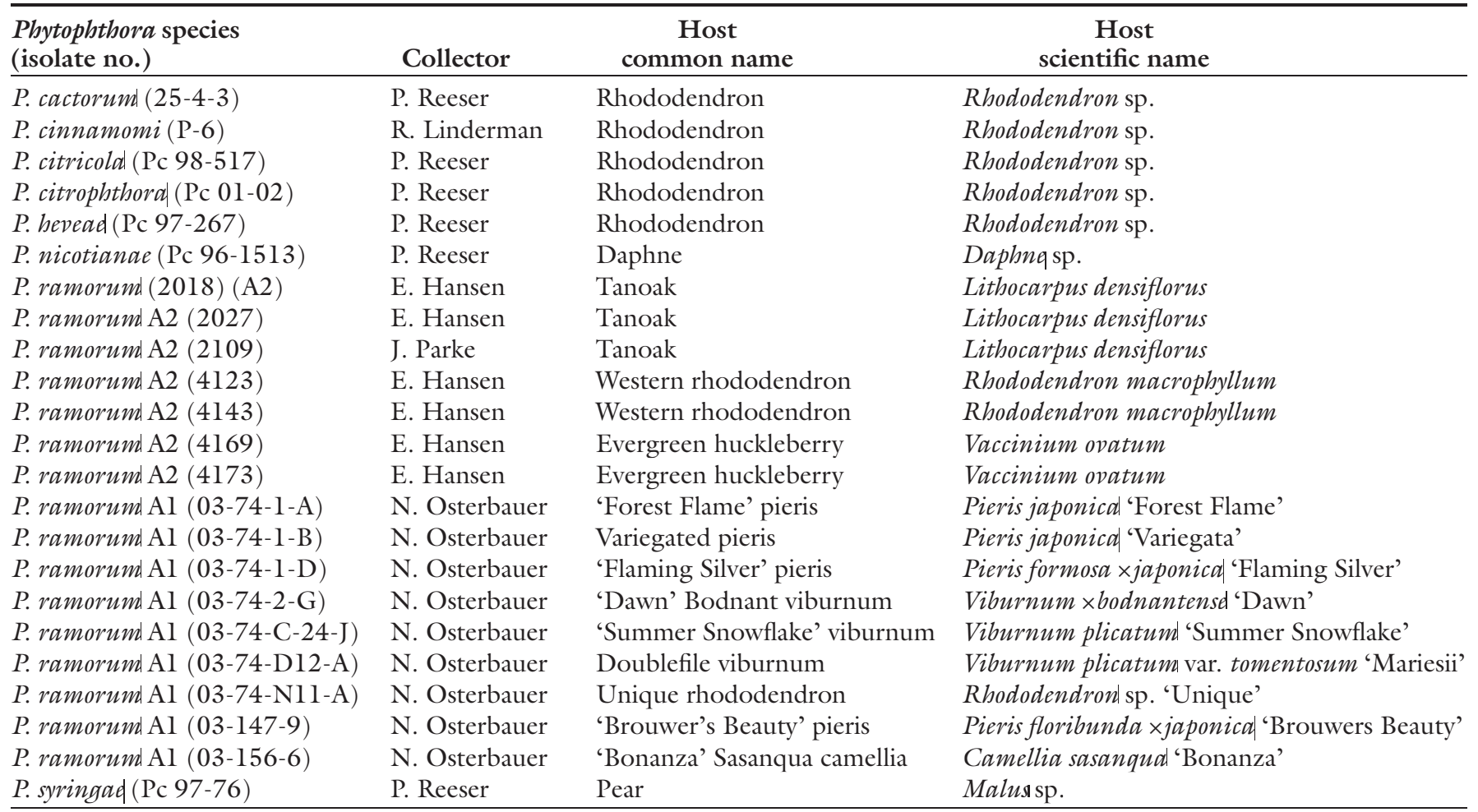

fourth. For larger-leaf species (such as rhododendron), three inoculum plugs were placed on one side of the leaf, while the control plug was placed on the opposite side of the midrib. For medium-sized leaves [such as english laurel (Prunus laurocerasus)], only two sites on a leaf were inoculated on one side. In all cases, enough leaves were inoculated to have 15 sites to rate per isolate. For large leaves, there were five replicate leaves; for smaller leaf species, three leaves on five small shoots were inoculated (15 leaves). Plant species were inoculated with all Phytophthora species in groups over time rather than all at once. Inoculated leaves were placed in moist, plastic box chambers with moist vermiculite in the bottom to maintain high humidity and free water on the leaf surface, and hand-misted with distilled water as the chambers were closed; leaves were misted two to three times during an experiment. The chambers were placed in an incubator for 7 to $14 \mathrm{~d}$ at $20^{\circ} \mathrm{C}$, and then leaves were rated visually for severity of lesion development. In the host susceptibility studies, we used a rating system to score the relative size and extent of spread of lesions from the inoculation site: $\mathrm{l}=$ no infection (no lesion beyond the plug); 2 = low susceptibility (lesion up to twice the diameter of the plug); $3=$ medium susceptibility (lesion diameter up to 2 $\mathrm{cm}$ (but not coalescing with adjacent inoculation sites); and 4 = high susceptibility (lesion greater than $2 \mathrm{~cm}$ and spreading to adjacent inoculation sites and across the mid-vein of the leaf or involving the entire leaf).

SUSCEPTIBILITY OF NURSERY CRops. Detached leaves of a range of nursery crops (listed in Table 2) were collected from plants in a home landscape that had not been treated with fungicides. Most of the leaves were collected from plants during the winter and up to early spring, and collection and inoculations were done in groups. Fully expanded, mature leaves were selected in preference over very young, succulent leaves.

SUSCEPTIBILITY OF VIBURNUM SPECIES. In another inoculation test, leaves from nine species of viburnum (Table 3) obtained from a single nursery were inoculated with all eight species of Phytophthora, including both A2 (found primarily in North America (culture 2027) and Al mating types (found primarily in Europe (culture 03-74D12-A) of $P$. ramorum. Inoculations were conducted as described above for medium- and large-leaf species and lesions were rated after $10 \mathrm{~d}$ of incubation.

Virulence OF ISOlates OF PHTTOPHTHORA ON RHODODENDRON,
VIBURNUM, AND LILAC. Mycelium plugs of species of Phytophthora, including multiple isolates of $P$. ramorum mating types $\mathrm{Al}$ and $\mathrm{A} 2$, were applied to detached leaves of 'Nova Zembla' rhododendron, doublefile viburnum, or lilac under identical conditions to determine relative virulence. Leaves were collected from container-grown (rhododendron) or landscape plants in late winter (10 Mar.) to early spring (4 May). Leaves were inoculated as described previously, with three replicate leaves used per isolate and four inoculum sites per leaf. Lesion area (percentage of leaf area) was assessed quantitatively at $8 \mathrm{~d}$ from digital photographs using ASSESS software (Lamari, 2002). This software was not available when we evaluated inoculations reported in Tables 2 and 3.

Statistical evaluation. Data from the inoculation trials with different potential host plants using a severity index rating system were analyzed by non-parametric statistics, analogous to multiple comparisons in traditional analysis of variance, using pairwise contrasts of pathogen and cultivar disease severity, respectively. Data for each experiment were analyzed separately, estimating probability values with 50,000 bootstrap samples using SAS (version 9.1 for Windows; SAS Institute, Cary, N.C.). The procedure 
Table 2. Relative susceptibility ratings of detached leaves from 32 nursery plants that were inoculated with eight species of Phytophthora (Expt. 1).

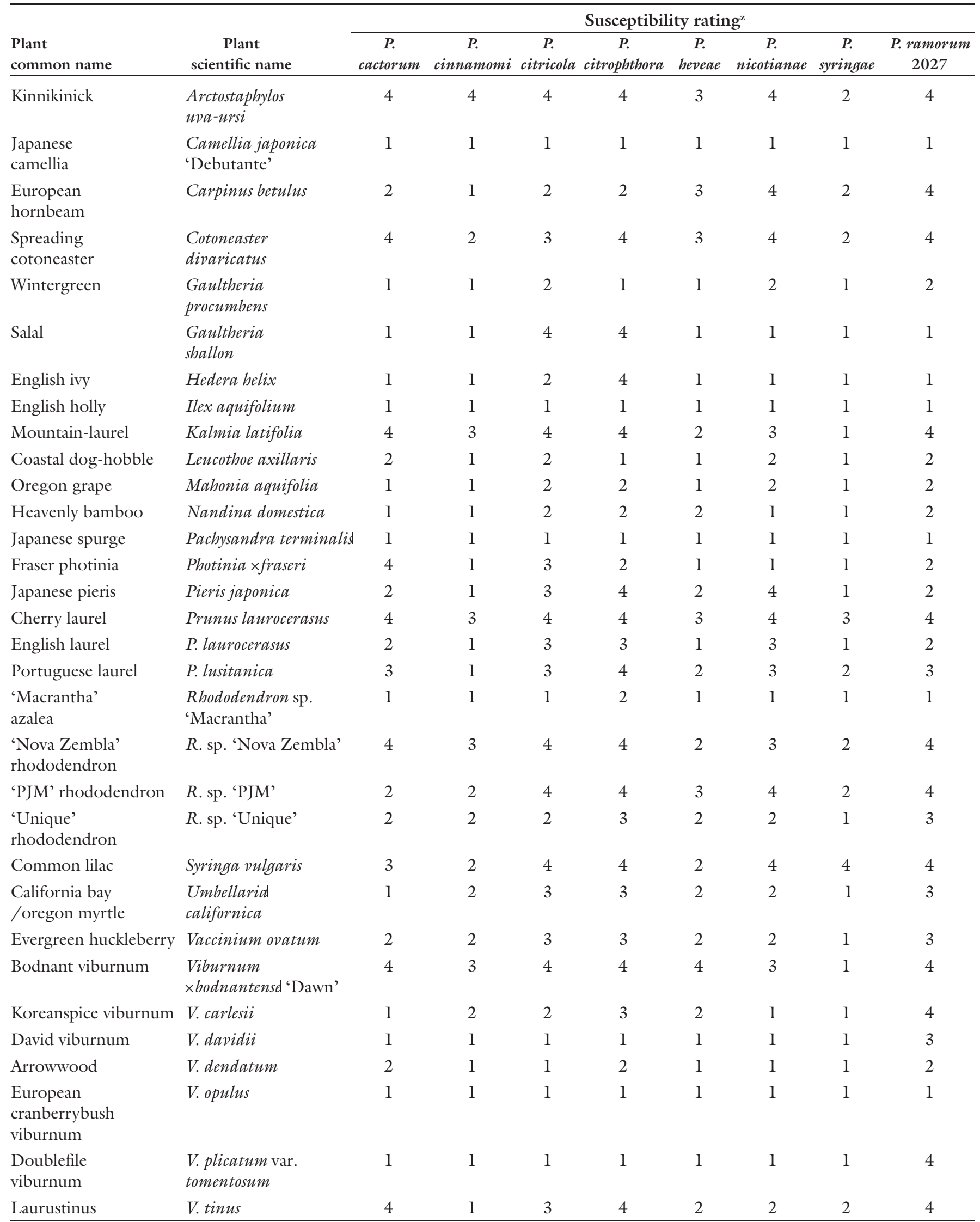

${ }^{\mathrm{L}}$ Susceptibility rating scale: 1 = no infection; 2 = low, $3=$ medium, and $4=$ high susceptibility. Ratings were the average of 15 inoculation sites on three or more leaves, rounded to the nearest whole number. Leaves were inoculated with mycelium plugs and placed in a moist chamber for 7 to $14 \mathrm{~d}$ at $20^{\circ} \mathrm{C}\left(68.0{ }^{\circ} \mathrm{F}\right)$. 
Table 3. Nonparametric multiple comparison to detect significant differences in resistance to Phytophthora in different ornamental crops listed in Table 2. Probability values were estimated using bootstrapping.

\begin{tabular}{|c|c|c|c|}
\hline \multirow[b]{2}{*}{ Plant common name } & \multirow[b]{2}{*}{ Plant scientific name } & \multicolumn{2}{|c|}{ Susceptibility rating ${ }^{z}$} \\
\hline & & Expt. 1 & Expt. 2 \\
\hline 'Nova Zembla' rhododendron & Rhododendron sp. 'Nova Zembla' & $3.6 \mathrm{a}$ & -- \\
\hline Kinnikinick & Arctostaphylos uva-ursi & $3.6 \mathrm{a}$ & --- \\
\hline Cherry laurel & Prunus laurocerasus & $3.6 \mathrm{a}$ & --- \\
\hline Lilac & Syringa vulgaris & $3.4 \mathrm{a}$ & --- \\
\hline Bodnant viburnum & Viburnum $\times$ bodnantense 'Dawn' & $3.3 \mathrm{ab}$ & --- \\
\hline Spreading cotoneaster & Cotoneaster divaricatus & $3.2 \mathrm{abc}$ & --- \\
\hline 'PJM' rhododendron & Rhododendron sp. 'PJM' & $3.0 \mathrm{abcd}$ & --- \\
\hline Mountain-laurel & Kalmia latifolia & $3.0 \mathrm{abcd}$ & --- \\
\hline Laurustinus & Viburnum tinus & $3.0 \mathrm{abcd}$ & --- \\
\hline Japanese pieris & Pieris japonica & $2.6 \mathrm{cde}$ & --- \\
\hline Portuguese laurel & Prunus lusitanica & $2.5 \mathrm{def}$ & --- \\
\hline 'Unique' rhododendron & Rhododendron sp. 'Unique' & $2.2 \mathrm{efg}$ & --- \\
\hline California bay/oregon myrtle & Umbellularia californica & $2.1 \mathrm{efgh}$ & --- \\
\hline Evergreen huckleberry & Vaccinium ovatum & $2.0 \mathrm{e}-\mathrm{i}$ & --- \\
\hline English laurel & Prunus laurocerasus & $2.0 \mathrm{e}-\mathrm{j}$ & --- \\
\hline Fraser photinia & Photinia $\times$ fraseri & $1.8 \mathrm{f}-\mathrm{j}$ & --- \\
\hline Koreanspice viburnum & Viburnum carlesii & $1.8 \mathrm{~g}-\mathrm{k}$ & --- \\
\hline Salal & Gaultheria shallon & $1.7 \mathrm{~g}-\mathrm{k}$ & --- \\
\hline European hornbeam & Carpinus betulus & $1.5 \mathrm{~g}-1$ & --- \\
\hline English ivy & Hedera belix & $1.5 \mathrm{~h}-1$ & --- \\
\hline Oregon grape & Mabonia aquifolium & $1.5 \mathrm{~h}-1$ & --- \\
\hline Wintergreen & Gaultheria procumbens & $1.4 \mathrm{~h}-1$ & --- \\
\hline Doublefile viburnum (1) & Viburnum plicatum var. tomentosum & $1.4 \mathrm{i}-1$ & --- \\
\hline Heavenly bamboo & Nandina domestica & $1.4 \mathrm{i}-1$ & --- \\
\hline Arrowwood & Viburnum dentatum & $1.4 \mathrm{i}-1$ & --- \\
\hline Coast leucothoe & Leucothoe axillaris & $1.3 \mathrm{jkl}$ & --- \\
\hline Doublefile viburnum (2) & Viburnum plicatum var. tomentosum & $1.3 \mathrm{jkl}$ & --- \\
\hline 'Macrantha' azalea & Rhododendron sp. 'Macrantha' & $1.3 \mathrm{jkl}$ & --- \\
\hline David viburnum & Viburnum davidii & $1.1 \mathrm{kl}$ & --- \\
\hline 'Debutante' japanese camellia & Camellia japonica 'Debutante' & 1.01 & -- \\
\hline English holly & Ilex aquifolium & 1.01 & --- \\
\hline European cranberrybush viburnum & Viburnum opulus & 1.01 & --- \\
\hline Japanese spurge & Pachysandra terminalis & 1.01 & --- \\
\hline Bodnant viburnum & Viburnum $\times$ bodnantense 'Dawn' & --- & $2.4 \mathrm{a}$ \\
\hline Burkwood viburnum & V. $\times$ burkwoodii & --- & $2.3 \mathrm{ab}$ \\
\hline Prague viburnum & $V . \times$ pragense & --- & $2.1 \mathrm{ab}$ \\
\hline Laureltinus & V. tinus 'Compactum' & --- & $2.0 \mathrm{ab}$ \\
\hline Leatherleaf viburnum & V. rhytidophylloides & --- & $1.7 \mathrm{ab}$ \\
\hline Doublefile viburnum & V. plicatum var. tomentosum 'Mariesii' & --- & $1.7 \mathrm{ab}$ \\
\hline Koreanspice viburnum & V. carlesii & --- & $1.6 \mathrm{bc}$ \\
\hline 'Christom' arrowwood & $V$. dentatum 'Christom' & --- & $1.2 \mathrm{c}$ \\
\hline
\end{tabular}

${ }^{2}$ Means of susceptibility ratings (Table 2 ) where 1 = no infection; 2 = low, 3 = medium, and 4 = high susceptibility. Ratings were the average of 15 inoculation sites on three or more leaves, rounded to the nearest whole number. Leaves were inoculated with mycelium plugs and placed in a moist chamber for 7 to $14 \mathrm{~d}$ at $20^{\circ} \mathrm{C}\left(68.0^{\circ} \mathrm{F}\right)$. Within each column, means followed by the same letter are not significantly different at $P \leq 0.05$.

MULTTEST was used for contrasts using step-down tests as implemented with the STEPBOOT option (Westfall et al., 1999).

Transformed data of Phytophthora isolate leaf lesion areas on three hosts, measured using ASSESS software, were analyzed by one-way analyses of variance (ANOVA). Treatment means of lesion areas were compared on each host using 95\% confidence intervals. Means that did not overlap at the $95 \%$ confidence interval were considered statistically different.

\section{Results}

SUSCEPTIBILITY OF NURSERY CROPS. Symptoms caused by all eight species of Phytophthora were similar on most host plants, being characterized generally as dark, necrotic lesions with discrete margins on some, diffuse on others, radiating out from the inoculation point without any zonal pattern.
Sometimes the lesion margin followed veinal patterns. However, some pathogen species were distinctly more virulent than others, as indicated by the size of the lesion they caused (Tables 2 and 3 ). Rhododendron, kinnikinick (Arctostaphylos uva-ursi), english laurel, cotoneaster, mountain-laurel, lilac, and viburnum were statistically the most susceptible to most Phytophthora species. Symptoms exhibited on some Prunusspecies were distinct large shot- 


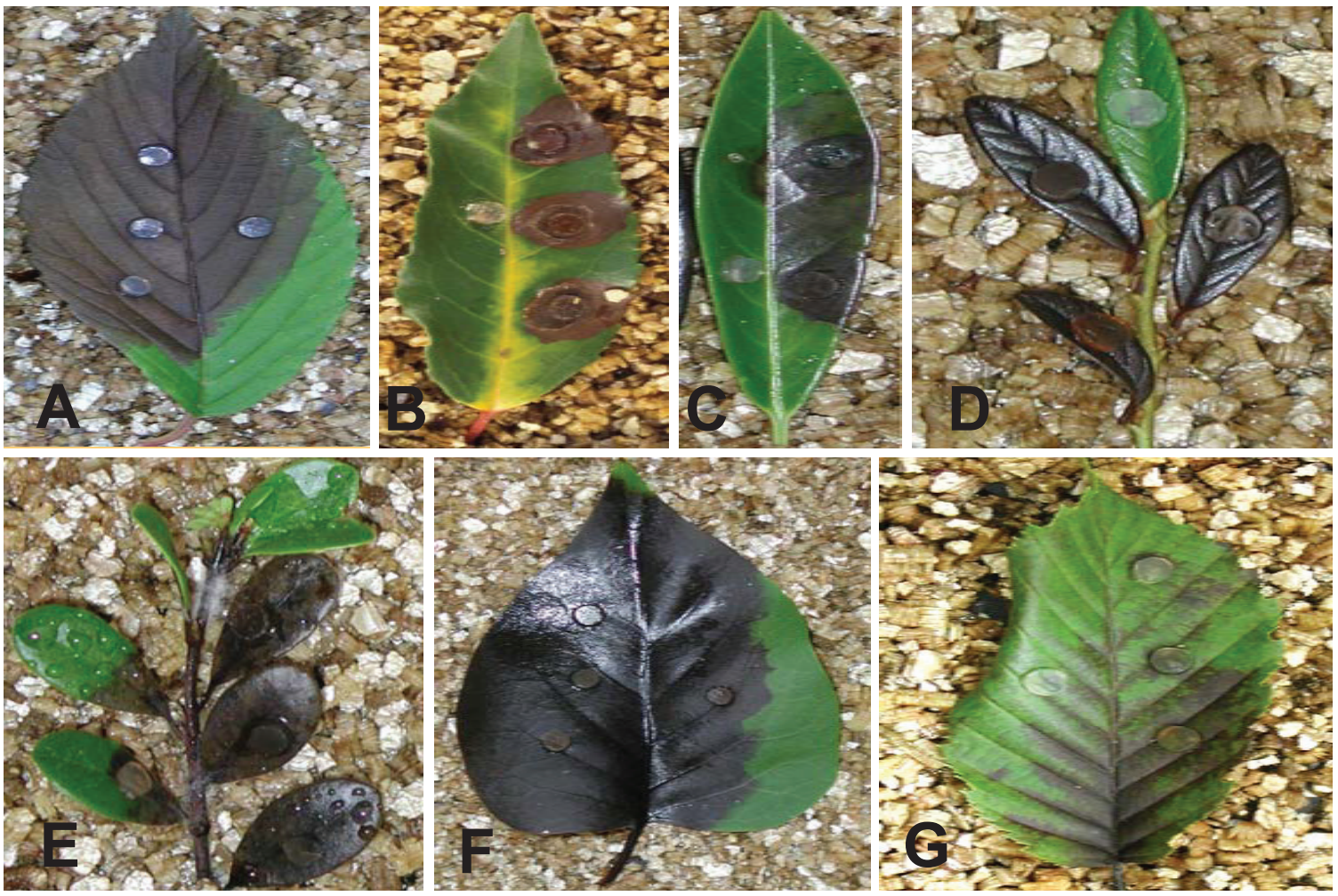

Fig. 1. Symptoms caused by Phytophthora ramorum A2 (isolate 2027) on detached leaves of: (A) doublefile viburnum ( Viburnum plicatum var. tomentosum), (B) portuguese laurel (Prunus lusitanica), (C) cherry laurel (Prunus laurocerasus), (D) spreading cotoneaster (Cotoneaster divaricatus), (E) kinnikinick (Arctostaphylos uva-ursi), (F) common lilac (Syringa vulgaris), and (G) european hornbeam (Carpinus betulus). Photos are not at the same scale. Leaves were inoculated with mycelium plugs and placed in a moist chamber for $14 \mathrm{~d}$ at $20^{\circ} \mathrm{C}\left(68.0{ }^{\circ} \mathrm{F}\right)$.

hole lesions that often dropped out of the leaf. Small-leaf plants, such as kinnikinick, cotoneaster, or evergreen huckleberry (Vaccinium ovatum) were severely infected and the lesion extended through the petiole into the stem tissue, often causing complete defoliation of the shoot (Fig. 1). Some viburnum species were susceptible to $P$. ramorum but not other isolates, while other plant species were susceptible to other Phytophthora species exclusive of P. ramorum [salal (Gaultheria shallon), english ivy (Hedera helix), and 'Macrantha' azalea (Rhododendron sp.)]. Some plants, such as holly (Hedera helix), japanese spurge (Pachysandra terminalis), european cranberrybush viburnum (Viburnum opulus), and 'Debutante' japanese camellia (Camellia japonica), were not infected at all by any species of Phytophthora. The three rhododendron cultivars inoculated were generally highly susceptible to inoculation with most species of Phytophthora, but 'Macrantha' azalea was not. The most severe symptoms caused by the most virulent Phytophthora species were larger than $2 \mathrm{~cm}$ in diameter, and often spread across the midvein.
Phytophthora ramorum, P. cactorum, $P$. citricola, P. citrophthora, and P. nicotianaewere the most virulent pathogens, often spreading throughout the entire leaf (Table 4).

LESION ASSAY OF VIBURNUM SPECIES. Inoculation of nine species of viburnum obtained from a single nursery resulted in varied responses (Table 5 ). This test was prompted by earlier (Table 2) inoculations indicating that david viburnum ( $V$. davidii) and doublefile viburnum were infected only by $P$. ramorum (isolate 2027 ) and none of the other species of Phytophthora. Most viburnum species were highly susceptible to either of two isolates of $P$. ramorum (A1 and A2 mating types) and most often not to any other Phytophthora species. Exceptions were the bodnant viburnum $(V . \times$ bodnatense 'Dawn'), prague viburnum ( $V . \times p r a-$ gense), and laureltinus ( $V$. tinus var. compactum) that were infected to some extent by several Phytophthora species. Burkwood viburnum (V.×burkwoodii) was susceptible to $P$. cactorum as well as the two P.ramorum isolates. These tests confirmed earlier indications that, in addition to david and doublefile vibur- nums, detached leaves of koreanspice viburnum ( $V$. carlesii), the leatherback viburnum ( $V$. rhytidophyllum), and 'Christom' arrowwood ( $V$. dendatum 'Christom') were susceptible only to $P$. ramorum under these test conditions. However, in other studies (J.L. Parke,

Table 4. Nonparametric multiple comparison to detect significant differences in virulence of different Phytophthora species on all hosts tested in Experiments 1 and 2 in Tables 2 and 4. Probability values were estimated using bootstrapping.

\begin{tabular}{lcc}
\hline Phytophthora species & Expt. $1^{\mathrm{z}}$ & Expt. 2 \\
\hline P. ramorum 2027 & $2.6 \mathrm{a}$ & $3.5 \mathrm{a}$ \\
P. ramorum D-12A & --- & $3.7 \mathrm{a}$ \\
P. citrophthora & $2.6 \mathrm{a}$ & $1.9 \mathrm{bc}$ \\
P. citricola & $2.4 \mathrm{ab}$ & $1.4 \mathrm{~cd}$ \\
P. nicotianae & $2.1 \mathrm{~b}$ & $1.1 \mathrm{~d}$ \\
P. cactorum & $2.0 \mathrm{bc}$ & $2.2 \mathrm{~b}$ \\
P. heveae & $1.7 \mathrm{~cd}$ & $1.0 \mathrm{~d}$ \\
P. cinnamomi & $1.5 \mathrm{de}$ & $1.0 \mathrm{~d}$ \\
P. syringae & $1.4 \mathrm{e}$ & $1.1 \mathrm{~d}$ \\
\hline
\end{tabular}

${ }^{\text {}}$ Means of susceptibility ratings where $\mathrm{l}=$ no infection; $2=$ low, $3=$ medium, and $4=$ high susceptibility. Within each column, means followed by the same letter are not significantly different at $P \leq 0.05$. 
Table 5. Relative susceptibility ratings of detached leaves of nine viburnum species obtained from a single nursery and inoculated with eight Phytophthora species (Expt. 2).

\begin{tabular}{|c|c|c|c|c|c|c|c|c|c|c|}
\hline \multirow[b]{2}{*}{$\begin{array}{l}\text { Common } \\
\text { name }\end{array}$} & \multirow[b]{2}{*}{$\begin{array}{l}\text { Viburnum species } \\
\text { scientific name }\end{array}$} & \multicolumn{9}{|c|}{ Susceptibility rating $\underline{\underline{z}}$} \\
\hline & & $\begin{array}{c}P . \\
\text { cactorum }\end{array}$ & $\begin{array}{c}P . \\
\text { cinnamomi }\end{array}$ & $\begin{array}{c}P . \\
\text { citricola }\end{array}$ & $\begin{array}{c}P . \\
\text { citrophthora }\end{array}$ & $\begin{array}{c}P . \\
\text { beveae }\end{array}$ & $\begin{array}{c}P . \\
\text { nicotianae }\end{array}$ & $\begin{array}{c}P . \\
\text { syringae }\end{array}$ & $\begin{array}{c}\text { P. vamorum } \\
2027\end{array}$ & $\begin{array}{l}\text { P. ramorum } \\
03-74-\mathrm{D} 12-\mathrm{A}\end{array}$ \\
\hline $\begin{array}{l}\text { Burkwood } \\
\text { viburnum }\end{array}$ & V. $\times$ burkwoodii & 4 & 1 & 1 & 1 & 1 & 1 & 1 & 4 & 4 \\
\hline $\begin{array}{l}\text { Koreanspice } \\
\text { viburnum }\end{array}$ & V. carlesii & 1 & 1 & 1 & 1 & 1 & 1 & 1 & 4 & 4 \\
\hline $\begin{array}{l}\text { David } \\
\text { viburnum }\end{array}$ & V. davidii & 1 & 1 & 1 & 1 & 1 & 1 & 1 & 3 & 3 \\
\hline $\begin{array}{l}\text { 'Christom' } \\
\text { arrowwood }\end{array}$ & $\begin{array}{l}V . \text { dendatum } \\
\text { 'Christom' }\end{array}$ & 1 & 1 & 1 & 1 & 1 & 1 & 1 & 2 & 2 \\
\hline $\begin{array}{l}\text { Prague } \\
\text { viburnum }\end{array}$ & $V . \times$ pragense & 3 & 1 & 1 & 4 & 1 & 1 & 1 & 4 & 4 \\
\hline $\begin{array}{l}\text { Leatherleaf } \\
\text { viburnum }\end{array}$ & V. rhytidophyllum & 1 & 1 & 1 & 1 & 1 & 1 & 1 & 4 & 4 \\
\hline Laurustinus & $\begin{array}{l}V . \text { tinus var. } \\
\text { compactum }\end{array}$ & 3 & 1 & 1 & 2 & 1 & 1 & 1 & 4 & 4 \\
\hline
\end{tabular}

${ }^{{ }^{2}}$ Susceptibility rating scale: $1=$ no infection; $2=$ low, $3=$ medium, and $4=$ high susceptibility. Ratings were the average of 15 inoculation sites on three or more leaves, rounded to the nearest whole number. Leaves were inoculated with mycelium plugs and placed in a moist chamber for 8 to $14 \mathrm{~d}$ at $20{ }^{\circ} \mathrm{C}\left(68.0{ }^{\circ} \mathrm{F}\right)$.

personal communication) where young foliage on intact david and doublefile viburnum plants was inoculated with different species of Phytophthora, including $P$. citricola and $P$. citrophthora, infections did occur by species other than $P$. ramorum.

Comparative Virulence ON RHODODENDRON, DOUBLEFILE VIBURNUM, OR LILAC. The relative virulence of $P$. ramorum isolates recovered from three different native host plants in Curry County, Ore., when inoculated on detached leaves of 'Nova Zembla' rhododendron varied considerably (Fig. 2). The severity of lesion development on detached leaves of 'Nova Zembla' rhododendron, doublefile viburnum, or lilac inoculated with each of eight Phytophthora species or multiple isolates of P. ramorum is shown in Fig. 3. Most of the Al mating type strains were more virulent than most of the A 2 mating type strains (Brasier, 2003; De Gruyter et al., 2002), and $P$. ramorum, P. citricola, $P$. nicotianae, and $P$. citrophthora were the most virulent species among the plant species tested (depending on the host species), thus confirming results from previous tests (Table 2 ) using only the P. ramorum A2 strain 2027. Some of the A2 mating type strains were less virulent on rhododendron leaves at the time of this test, even though all the isolates were from the same infection location (although from different host plants) in Curry County, Ore., and had been maintained under identical cultural conditions. Furthermore, the virulence pattern shown on rhododendron was not the same as those on lilac or viburnum. The data suggest some degree of host preference by some of the A2 isolates, less so for the Al isolates, which may have been the same, all coming from different hosts at the same nursery. The high virulence of $P$. citricola and $P$. citrophthora on lilac and rhododendron was evident; the high virulence of $P$. nicotianae on rhododendron but not lilac also indicated host preference by those species of Phytophthora. The susceptibility of some viburnums only to isolates of $P$. ramorum was also confirmed under the conditions of this test.

\section{Discussion}

The results of these studies indicate that a wider range of nursery and landscape plants than previously reported could be susceptible to infection by species of Phytophthora, including $P$. ramorum. Tooley et al. (2004) demonstrated a wider host range of ericaceous plant species than had been reported to be infected in nature. At the time of initiating our report, the official list of naturally infected plants contained 31 hosts, and 37 "associated" hosts for which Koch's postulates had not been completed. Since then many of the host plants that were highly susceptible in our tests have been found infected naturally and Koch's postulates have been satisfied for each. Our study indicated that plant exposure where inoculum is available and abundant resulted in infections of many more plant species. Mountain-laurel and lilac have already been reported to be highly susceptible (Beales et al., 2004b; Tooley et al., 2004), and we found commonly grown plants, such as cherry laurel (Prunus laurocrasus), cotoneaster, and laurustinus (Viburnum tinus), to be equally susceptible. However, camellia, though infected naturally in the landscape or nurseries (Beales et al., 2004a; Parke et al., 2004), were not susceptible in our tests. Different cultivars of the same species exhibited different levels of susceptibility, and the 'Debutante' camellia was not susceptible, even with the severe inoculation method used in the study.

In other trials we also dem- 


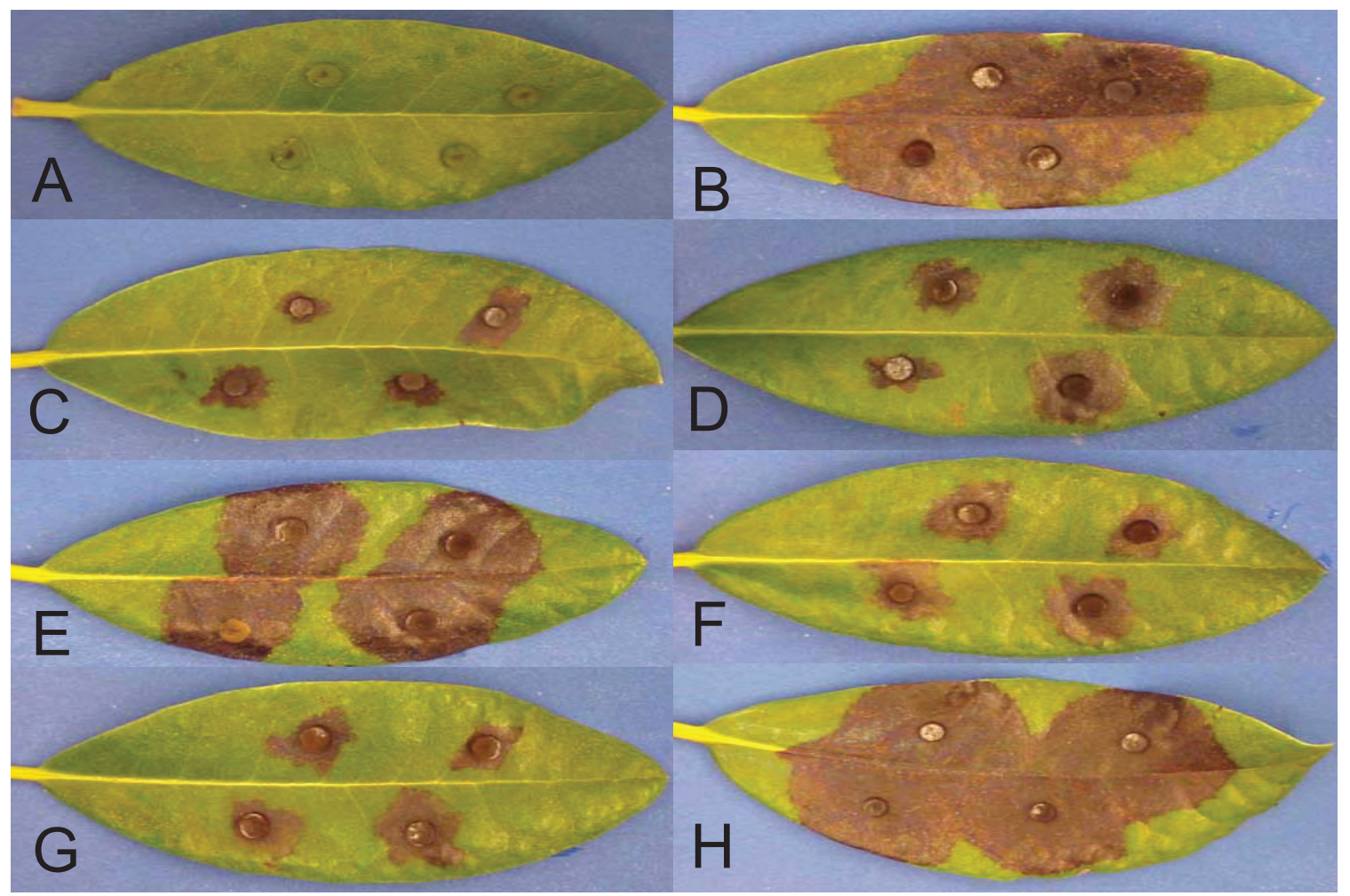

Fig. 2. Lesions on detached leaves of 'Nova Zembla' rhododendron after $14 \mathrm{~d}$ of incubation at $20^{\circ} \mathrm{C}\left(68.0{ }^{\circ} \mathrm{F}\right)$ caused by mycelium plugs of different isolates of Phytophthora ramorum, recovered from diseased native plants in Curry County, Ore. (A) Control; (B and C) isolates 4123 and 4143, respectively, from western rhododendron (Rbododendron macrophyllum); (D and $\mathrm{E}$ ) isolates 4169 and 4173, respectively, from evergreen huckleberry (Vaccinium ovatum); (F-H) isolates 2018, 2027, and 2109, respectively, from tanoak (Lithocarpus densiflorus). Photos were taken at the same scale.

onstrated variability in susceptibility among species as well as cultivars within viburnum species (unpublished results). This variability increases the difficulty of inspections and surveys in that all cultivars or species should be inspected for symptoms in nurseries. Furthermore, there are host plant species that were only mildly susceptible to inoculation with $P$. ramorum or other Phytophthora species, and they could easily be overlooked due to lack of distinct symptoms. These results suggest that more plant species and cultivars should be surveyed for early detection of $P$. ramorum and other pathogenic species in nurseries and landscapes, a need that may not be met for economic reasons. We note that susceptibility of a plant to a species of Phytophthora in our assays might not be an accurate indication of the virulence of the fungus under longer incubation or under different inoculation conditions. For example, $P$. syringae is known to be a virulent pathogen on rhododendrons in nurseries (Linderman, 1986), yet it showed relatively low virulence in our tests. The physiological state of plants used in our inoculations could well be significantly different than that of plants used in other inoculations. Different cultural practices may well modify host susceptibility, and they need to be investigated.

In our studies P. ramorum, compared to other species of Phytophthora, caused similar symptoms on any given host where it was shown to be highly virulent. On hosts whose susceptibility was comparable to that of $P$. cactorum, $P$. citricola, $P$. nicotianae, and $P$. citrophthora, symptoms between the isolates were the same. The relatively low infectivity of species such as $P$. syringae and $P$. heveae may be due to the time of year when inoculations were done. Low infectivity with $P$. cinnamomi may be due to it being primarily a root pathogen. Also, this is the first report of rhododendron leaf susceptibility to infection by $P$. citrophthora, and its high virulence, comparable to that of $P$. ramorum, should be noted. Study results indicate that $P$. ramorum may pose a higher risk potential than other species found in nurseries, since it is able to sporulate (both sporangia and chlamydospores) more profusely on solid media than any other species of Phytophthora tested (personal observation). Our experiment comparing isolates of $P$. ramorum on 'Nova Zembla' rhododendron, doublefile viburnum, or lilac leaves also indicated the capacity of this species to have or develop genetic variation by some asexual means (Brasier, 2003; Caten and Jinks, 1968). Although variation in isolate virulence was evident on a single host, mutation and concomitant loss of virulence had not occurred in culture, since low virulence on one host was not seen on the other hosts (Fig. 3).

Despite the highly consistent response in our inoculation trials, we noted that there was considerable variation within a plant species in susceptibility of leaves on the same plant or inoculation sites on the same leaf. Rarely, this was the result of the inoculum plug slipping off the wound site; thus, no lesion would result. Other times this was not the explanation, yet some leaves or wound sites did not become infected. This observation un- 

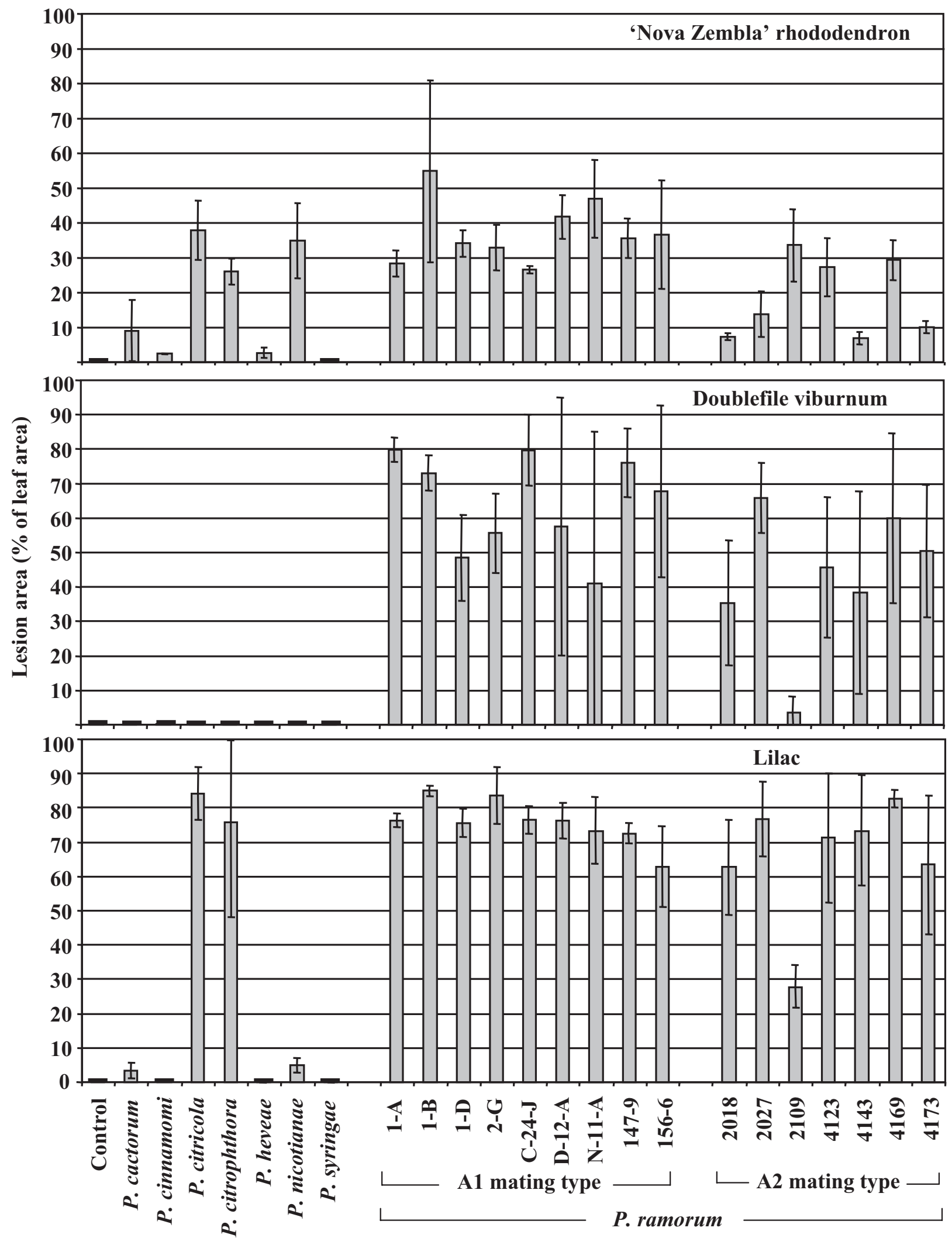

Fig. 3. Lesion size (percentage of leaf area) on detached leaves of 'Nova Zembla' rhododendron, doublefile viburnum ( $V i$ burnum plicatum var. tomentosum), and common lilac (Syringa vulgaris) inoculated with mycelium plugs of Phytophthora species, including multiple isolates of $P$. vamorum. Inoculated leaves were incubated in a moist chamber for $8 \mathrm{~d}$ at $20{ }^{\circ} \mathrm{C}$ $\left(68.0^{\circ} \mathrm{F}\right)$. Lesion area was determined from ASSESS software as percentage of leaf area. Each column value is the mean of three replicate leaves with four inoculation sites per leaf. Vertical bars for each mean are $95 \%$ confidence intervals. Complete code numbers for all Phytophthora isolates are given in Table 1. 
derscores the need to determine physiological, environmental, and cultural practices or factors that might increase or decrease susceptibility, including uneven distribution of resistance factors within a plant. Variation in distribution of nutrients within the plant or variation in leaf morphology also could be involved, and these possibilities need further investigation.

While all of our inoculations were conducted on detached leaves, we made similar wound-site inoculations on intact 'Nova Zembla' rhododendron plants maintained in polyethylene bags under high humidity, and achieved similar results (data not shown). This indicated that the results obtained from the detached leaf inoculation test were valid. Furthermore, the fact that we had significant variation in infectivity of leaves, using both different plant species and different Phytophthora species, supports the use of the detached leaf assay as a meaningful test. Within this context, we acknowledge that our detached leaf assay gives relative comparisons, and does not necessarily reflect the absolute susceptibility or resistance of a plant under any other set of conditions or inoculation method. Inoculation with mycelium plugs placed on wounds represents a severe test of host susceptibility that might yield some false positive results, as compared to the more natural form of sporangia or zoospore inoculum. However, negative responses under those severe inoculation conditions indicates the probability of them being low-risk plants, information that would be of significance to nurseries.

\section{Literature cited}

Beales, P.A., T. Brodensire, A.V. Barnes, V.C. Barton, and K.J.D. Hughes. 2004a. First report of ramorum leaf blight and dieback (Phytophthora ramorum) on Camellia spp. in the UK. Plant Pathol. 53:524.

Beales, P.A., A. Schlenzig, and A.J. Inman. $2004 \mathrm{~b}$. First report of ramorum bud and leaf blight (Phytophthora ramorum) on Syringa vulgaris in the UK. Plant Pathol. 53:525.

Benson, D.M. and S. von Broembsen. 2001. Phytophthora root rot and dieback, p. 52-56 In: R.K. Jones and D.M. Benson (eds.). Diseases of woody ornamentals and trees in nurseries. APS Press, St. Paul, Minn.

Brasier, C. 2003. Sudden oak death: Phytophthora ramorum exhibits transatlantic differences. Mycol. Res. 1007:258-259.

Caten, C.C. and J.L. Jinks. 1968. Spontaneous variability of single isolates of Phytophthora infestans. I. Cultural variation. Can. J. Bot. 46:329-348.

Coyier, D.L. and M.K. Roane (eds.). 1986. Compendium on rhododendron and azalea diseases. Amer. Phytopathol. Soc., St. Paul, Minn.

Daughtrey, M.L. and D.M. Benson. 2001. Rhododendron diseases, p. 334-341. In: R.K. Jones and D.M. Benson (eds.). Diseases of woody ornamentals and trees in nurseries. APS Press, St. Paul, Minn.

Davidson, J.M., S. Werres, M. Garbelotto, E.M. Hansen, and D.M. Rizzo. 2003. Sudden oak death and associated diseases caused by Phytophthora ramorum. 12 Oct. 2005. <http://www.plantmanagementnetwork.org/pub/php/diagnosticguide $/ 2003 / \operatorname{sod} />$.

De Gruyter, H., R. Baayen, J. Meffert, P. Bonants, and F. van Kuik. 2002. Comparison of pathogenicity of Phytophthora ramorum isolates from Europe and California. Sudden Oak Death Sci. Symp., 15-18 Dec. 2002, Monterey, Calif. 12 Oct. 2005. <http://danr.ucop.edu/ihrmp/ sodsymp/paper/paper10.html>.

Goheen, E., E. Hansen, A. Kanaskie, M. McWilliams, N. Osterbauer, and W. Sutton. 2002. Sudden oak death, caused by Phytophthora ramorum, in Oregon. Plant Dis. 66:441.
Lamari, L. 2002. ASSESS: Image analysis software for plant disease quantification. APS Press, St. Paul, Minn.

Linderman, R.G. 1986. Phytophthora syringae blight, p. 15-17. In: D.L. Coyier and M.K. Roane (eds.). Compendium on rhododendron and azalea diseases. APS Press, St. Paul, Minn.

Linderman, R.G., J.L. Parke, and E.M. Hansen. 2002. Relative virulence of Phytophthora species, including the sudden oak death pathogen $P$. ramorum, on several ornamental species. 12 Oct. 2005. <http://www.apsnet.org/meetings/2002/abstracts/a02ma342.htm>.

Osterbauer, N.K., J.A. Griesbach, and J. Hedberg. 2004. Surveying for and eradicating Phytophthora ramorum in agricultural commodities. 12 Oct. 2005. <http://www. plantmanagementnetwork.org/pub/php/ research/2004/pramorum>.

Parke, J.L., R.G. Linderman, N.K. Osterbauer, and J.A. Griesbach. 2004. Detection of Phytophthora ramorum blight in Oregon nurseries and completion of Koch's postulates on Pieris, Rhododendron, Viburnum, and Camellia. Plant Dis. 88:87.

Ribeiro, O.K. 1978. A source book of the genus Phytophthora. J. Cramer, Vaduz, Fla.

Rizzo, D.M., M. Garbelotto, J.M. Davidson, G.W. Slaughter, and S.T. Koike. 2002. Phytophthora ramorum as the cause of extensive mortality of Quercus spp. and Lithocarpus densiflorus in California. Plant Dis. 86:205-214.

Tooley, P.W., K.L. Kyde, and L. Englander. 2004. Susceptibility of selected ericaceous ornamental host species to Phytophthora ramorum. Plant Dis. 88:993-999.

Werres, S., R. Marwitz, W.A. Man In't Veld, W.A.M. De Cock, P.J.M. Bonants, M. De Weerdt, K. Themann, E. Ilieva, and R.P. Baayen. 2001. Phytophthora ramorum sp. nov: Anew pathogen on Rhododendron and Viburnum. Mycol. Res. 105:1155-1165.

Westfall, P.H., R.D. Tobias, D. Rom, R.D. Wolfinger, and Y. Hochberg. 1999. Multiple comparisons and multiple tests using the SAS system. SAS Inst., Cary, N.C. 